\title{
PAEONIA EMODI: A THREATENED IMPORTANT MEDICINAL PLANT OF HIGHER HIMALAYAN REGION
}

\author{
Vijay Kant Purohit ${ }^{1}$, Praveen Joshi ${ }^{1} \bowtie$ (D) Jaidev Chauhan ${ }^{1}$ and Prem Prakash ${ }^{2}$ \\ ${ }^{1}$ High Altitude Plant Physiology Research Centre (HAPPRC), H.N.B. Garhwal University, Srinagar (Garhwal)- \\ 246174, Uttarakhand, India. \\ ${ }^{2}$ M.B. Government P.G. College, Haldwani, Nainital-263139, Uttarakhand, India.
}

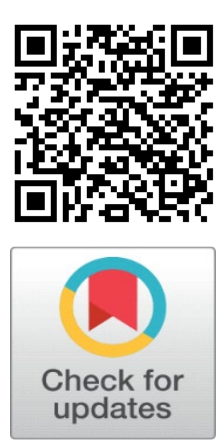

Received 3 August 2021

Accepted 17 August 2021

Published 31 August 2021

\section{CorrespondingAuthor}

Dr. Praveen Joshi,

praveenjoshipj88@gmail.com

DOI

10.29121/granthaalayah.v9.i8.2021. 4173

Funding: This research received no specific grant from any funding agency in the public, commercial, or not-for-profit sectors.

Copyright: (C) 2021 The Author(s). This is an open access article distributed under the terms of the Creative Commons Attribution License, which permits unrestricted use, distribution, and reproduction in any medium, provided the original author and source are credited.

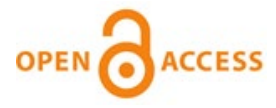

\section{ABSTRACT}

Himalaya is well known for its rich biodiversity with respect to medicinal and aromatic plants and Paeonia emodi Wall. ex Royle is one of them locally known as Chandra (family Paeoniaceae). In India, it is distributed in North-West Himalaya from Kashmir to Garhwal-Kumaun regions of Uttarakhand with an altitudinal range of 1800 to $2800 \mathrm{~m}$ asl. The whole plant of P. emodi is highly effective for uterine diseases, blood purifier, colic, bilious, backbone ache, headache, dizziness, vomiting, dropsy, epilepsy and hysteria while the seeds are purgative. A present phytosociological study particularly in Garhwal Himalaya, reveals that only few pockets of P. emodi are higher dense in Triyuginarayan and Shyalmi areas (3.80 and 2.72 individual $/ \mathrm{m} 2$ respectively) while remaining are lower dense under diverse climatic conditions due to invasion by several biotic and abiotic factors. Using available information based on field survey, it assumed that the causes of its degradation are largely overexploitation of immature twigs before flower formation and seed shedding. To conserve the targeted species for future prosperity, Government needs to take immediate and concrete initiatives or imposed the ban on illegal collection or removal of the plant from its natural populations and emphasize the promotion of conservation.

Keywords: Paeonia Emodi, Garhwal Himalaya, Medicinal and Aromatic Plants, Phytosociological Study, Anthropogenic Pressure

\section{INTRODUCTION}

Himalaya is well known for its rich biodiversity with respect to medicinal and aromatic plants. Owing to its unique geographical setup, topography and undulant landscape the climatic conditions varied along an altitudinal gradient which attributes diversified ecological habitat ranging from tropical forest, grassland to alpine meadows with vast and diverse natural resources. It supports over 675 species of wild edible plants and holds many largest and youngest mountain chains and covering an area about 2,36000 Km2 Kala (2005), Malik et al. (2015). It is well said fact that numbers of plant species are threatened at different levels due to impact of climate change, urbanization, extensive agriculture and anthropogenic pressure in terms of trampling, deforestation, overexploitation as well as unsustainable harvesting Maikhuri et al. (1998), Vashistha et al. (2006), Kandari et al.(2012). Unfortunately, some of these natural resources, mostly high-altitude medicinal plants are unscientifically exploited for various purposes such as drug and pharmaceutical industries, traditional use and research purposes from their natural populations and this activity has adversely 
affected the existence of numbers of high commercial valued plants. The medicinal plants are rich in secondary metabolites as well as a good source of herbal drugs. These secondary metabolites include alkaloids, glycosids, coumarins, flavonoids, steroids, etc. are varying from plants to plants in various environmental and climatic conditions Riaz et al. (2013). Plants which grow well in forest region, classified as minor forest products, supply a substantial amount of raw material required for the indigenous industry. Most of these plants can subsist under stress conditions and are thus suited even for rained cultivation of medicinal plants offering considerable scope for rural employment and export for foreign-exchange Munir et al. (2018).

Since mentioned anthropogenic pressure and developmental activities in the higher Himalayan region without rehabilitation work of these valuable resources, the original populations of many of them have been vanishing Maikhuri et al. (1998), Nautiyal et al. (2001), Semwal et al. (2007), Chen et al. (2013). However, in the Himalayan region number of high valued medicinal plant species is found growing and Paeonia emodi is one of them. Despite of having huge medicinal properties and descent income generating potential for rural peoples, it could not get much attention on conservation and cultivation particularly in areas near by its natural habitats.

Paeonia emodi Wall. ex Royle, locally known as Chandra is an important member of family Paeoniaceae, which is largely distributed in North-West India (from Kashmir to Garhwal-Kumaun regions of Uttarakhandand), Northern Pakistan, East Afghanistan, China and West Nepal De-yuan (1997) with an altitudinal range of 1800 to $2800 \mathrm{~m}$ asl Rawat et al. (2010). The species is well flourishes in the moist and sandy to loam soil within the understory of deciduous mixed forest like Oak and Pine species Joshi et al. (2017). It is an erect, leafy perennial glabrous herb, 50-70 cm long with biternate or ternate, lamina pale leaves with solitary and axillary flowers. The flowering and fruiting time of the species is between May to August Joshi et al. (2017).

The rhizome of $\mathrm{P}$. emodi is highly effective medicine for uterine diseases, blood purifier, colic, bilious, backbone ache, headache, dizziness, vomiting, dropsy, epilepsy and hysteria while the seeds are purgative Shinwari et al. (2003),Hamayun (2004), Ahmad and Sher (2004). Report indicates that P. emodi has the haemagglutination activity and it is a good source of lectins Benevides et al. (1999). Many reports also revealed that the crude extract of P. emodi have the antifungal and antimicrobial activity against the fungi and bacteria and useful in evaluating the toxicity of the extract Khan et al. (2005). The insecticidal activity of the crude extract of P. emodi was found interested in the discovery of botanical insecticides as alternatives to the synthetic ones, which possess well-known adverse effects on agro ecological systems Pavela (2004). Scientifically it has various other physiological activities including prevention of epileptic attacks, cholera and whooping cough Watt (1982).

Due to the multipurpose uses of P. emodi, the species is being used and continuous harvesting by the inhabitants of Garhwal Himalayan region since past. However, the species could not gain the significant place in the large scale. Therefore, documentation of traditional knowledge and population density is required to assess the current status. The findings of the study may be requisite in the promotion of traditional healthcare system and formation of conservation strategies of the targeted species in its natural habitats. 


\section{MATERIAL AND METHODS}

\subsection{STUDY AREA}

The study was carried out in randomly selected villages in Garhwal region of Uttarakhand, India i.e., Triyuginarayan, Pothivasa, Randhar Bangar, Gwaldam and Shyalmi (Table 1 Figure 1). The detailed location lies between $30^{\circ} 01^{\prime} 35^{\prime \prime} \mathrm{N}$ to $31^{\circ} 08^{\prime} 58^{\prime \prime} \mathrm{N}$ latitude and $78^{\circ} 06^{\prime} 09.2^{\prime \prime} \mathrm{E}$ to $79^{\circ} 31^{\prime} 04^{\prime \prime} \mathrm{E}$ longitude along analtitudinal gradient of 1800 to $2800 \mathrm{~m}$ asl. The NASA Shuttle Radar Topographic Mission (SRTM) Digital Elevation Model (DEM) data, which has a spatial resolution of $90 \mathrm{~m}$ and is available on the CGIAR-CSI website (2018), was used to display elevation information in the study area map.

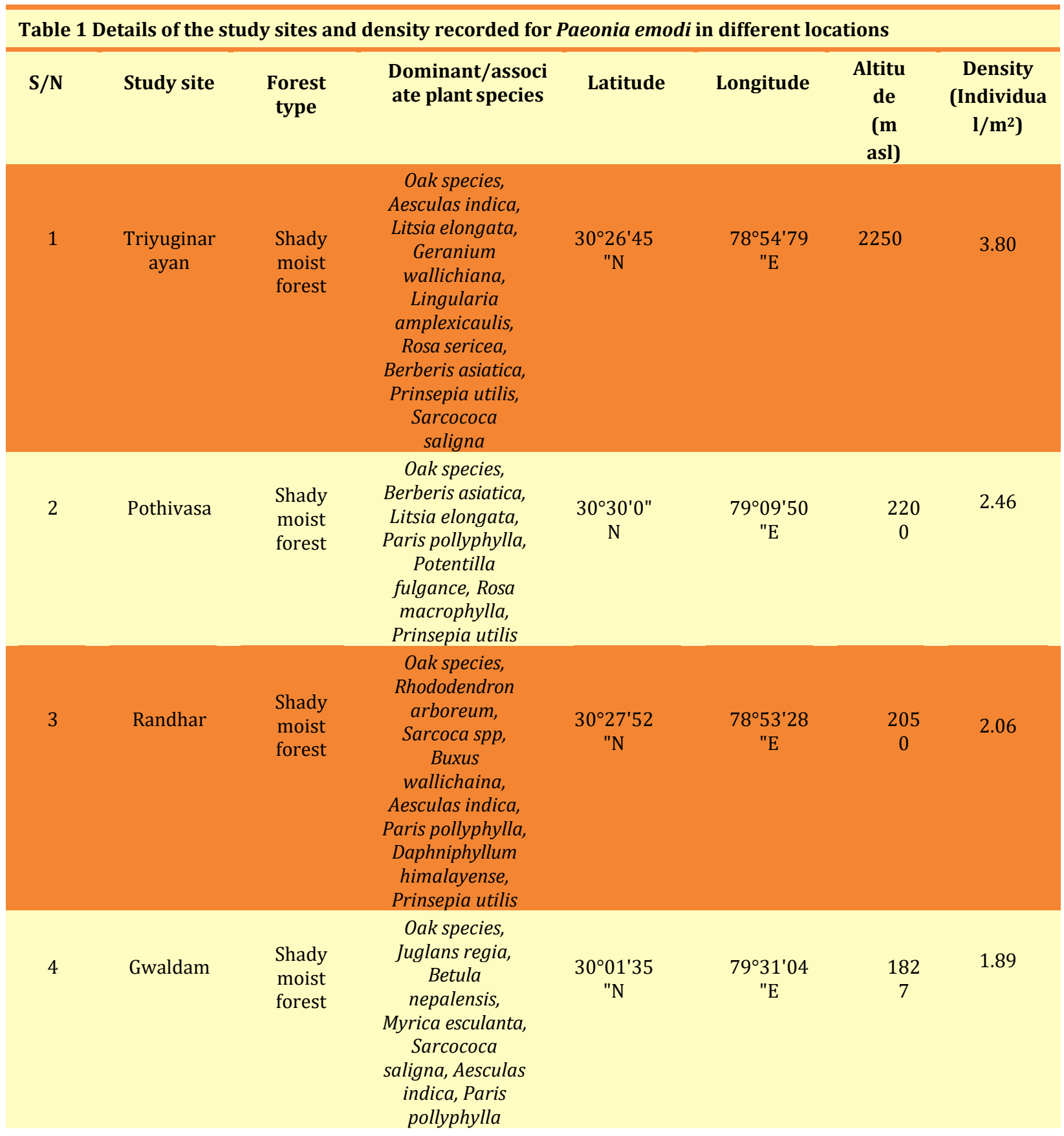



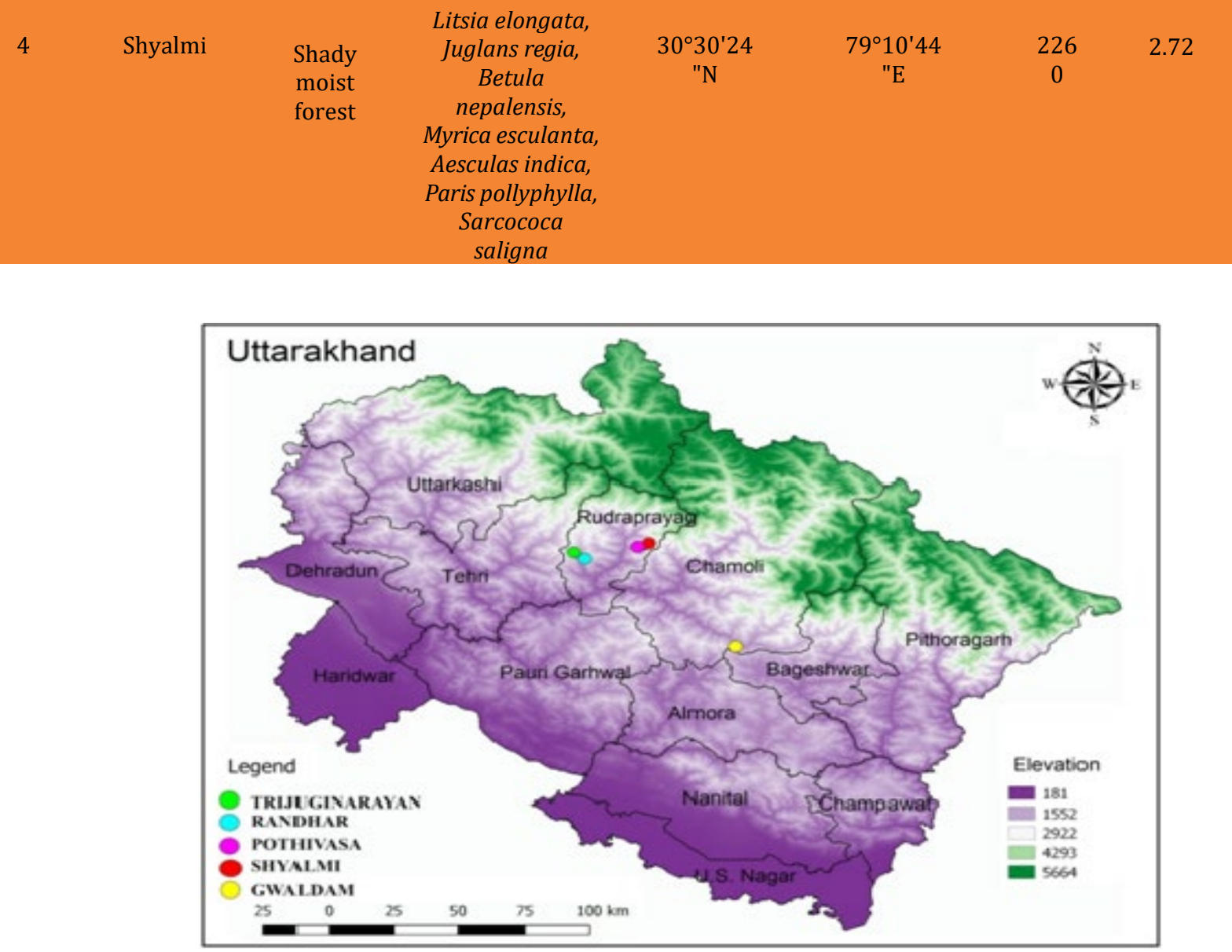

Figure 1 Different locations of study sites in Uttarakhand (Source: CGIAR-CSI (2018))

\subsection{DATA COLLECTION}

Extensive field surveys were conducted from May 2018 to August 2019 and the study populations were selected after exploring each site with the concern of local representatives. For the present task, months of July and September (Rainy season) were selected for collection of data on vegetation assessment so as to ensure maximum coverage of population.

Village meetings and general interaction done with the prior consent of villagers, about $40 \%$ of the inhabitants were interviewed regarding their dependence on forest resources particularly for the collection of medicinal plants and wild edibles. The informants/participants were of different age groups viz., younger to older. Semi-structured questionnaire was developed in English and Hindi. Information such as local name of the plant, part use, diseases for which plant or plant part is used, traditional consumption methods and recipes of preparation were documented based on interview. For verification of information, group discussions were held with local inhabitants and herbal practitioners (Vaidhyas or Dai) of the villages following the previous studies (Phondani et al., 2010) Dhyani et al. (2011),Negi et al. (2018). Quadrate method Misra (1968) was used to study the plant density. For sampling, $1 \times 1 \mathrm{~m}$ quadrates were randomly laid down. 


\subsection{SPECIES IDENTIFICATION}

Specimen was identified with the help of regional floras Naithani (1984), Gaur (1999). Local names of the plant were recorded with the help of local inhabitants and old aged traditional healers (Vaidhyas). However, the final taxonomic authentication was established after consulting with the help of plant taxonomist. A voucher specimen of P. emodi was preserved by following the standard herbarium methods Jain and Rao (1977) and submitted in the herbaria of Botanical Survey of India, Dehradun, Uttarakhand (BSI/NRC-Tech/Herb/Ident. /2017-18/plant accession no.118052).

\section{RESULT AND DISCUSSION}

According to local inhabitants of the higher Himalayan region in Uttarakhand, the soup and cooked vegetables from immature twigs of P. emodi are very useful for diabetic patient and also in improvement of body resistance. Therefore, they collect the species for the said purpose during February and March. Traditionally, the leaf and stem in juvenile phase are used as a wild edible (fresh vegetable) by local inhabitants while fleshy roots are used for treatment of uterine diseases and as blood purifier. Due to its medicinal properties and demands, local peoples are also preparing bio-prospecting products such as pickle and dry chunks to enhance their economic status in few regions of the study area. Similar findings were observed by Joshi et al. (2018) from the Garhwal Himalaya.

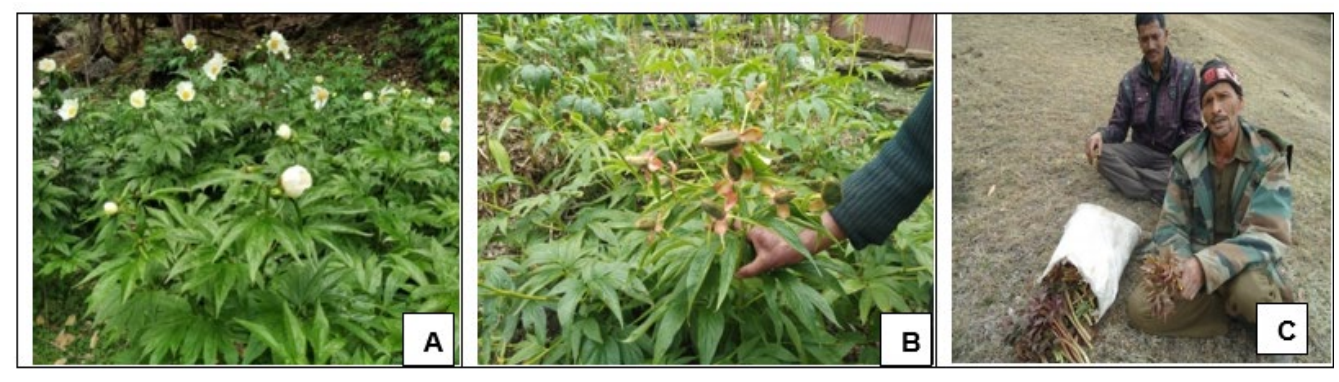

Figure 2 Mature plants of Paeonia emodi (A-B) and collected immature twigs by villagers for consumption (C).

During the present study it was found that the plant is still collected by local peoples from the wild in unscientific manner (immature twigs before seed shedding) to fulfill demands for manufacturing the local products such as pickle, dry chunks and juice which is rapidly pushing the plants in high degree of risk in its habitats (Figure 2). Our findings were agreed with Joshi et al. (2018) with respect to bioprospecting of P. emodi for livelihood enhancement in Western Himalayan region.

A reconnaissance done by the research team working on its conservation in Uttarakhand, particularly in Garhwal Himalayas, reveals that, only few pockets or individuals of P. emodi are higher dense in Triyuginarayan, Shyalmi areas (3.80 and 2.72 individual $/ \mathrm{m} 2$ respectively) while remaining are lower dense under diverse climatic conditions (Table 1). In fact, the remaining intact patches are also decreasing rapidly due to invasion by several biotic and abiotic factors such as soil properties, forest fire, trampling by animal and human interferences. Similar kind of study by Prakash et al. (2020) revealed that Low population density of P. emodi along with increasing elevation is due to the unfavorable climatic conditions and 
lack of association with tree species like Oak, Pine and Rhododendron. Using available information based on present field survey, it is assumed that the causes of its degradation are largely overexploitation of immature twigs before flower formation and seed shedding, low regeneration in the natural habitats, lack of awareness about the propagation methods, clearing of forests for developmental activities, i.e., constructions of roads and canals in many natural habitats.

\section{CONCLUSIONS}

To conserve P. emodi for future prosperity, government needs to take immediate and concrete initiatives or imposed the ban on illegal collection or removal of the species from its natural populations and emphasize the promotion of conservation. Keeping in view of the importance and conservation value of P. emodi ,some important conservation measures need to be applied, i.e., notify the natural populations for the protection of its habitats, detailed study on phenology with understanding of whole life cycle, sustainable collection of plants for commercial use, development of efficient propagation methods for developing large scale planting materials, establishment of nurseries in nearby areas for easy availability of plants to local peoples, rehabilitation of species before taking any developmental activities, creation of awareness among the local peoples about loss through over exploitation and promotion of cultivation in farmers' fields. Since policy-makers and scientist cannot conserve the species without wider support from the local communities and government agencies particularly forest department, a multifaceted effort is required to conserve the species in the long run.

\section{ACKNOWLEDGEMENT}

The authors are gratefully acknowledged the Director, High Altitude Plant Physiology Research Centre (HAPPRC) for providing facilities. Special thanks to the villagers and traditional herbal healers for sharing the information.

\section{CONFLICTS OF INTEREST}

The authors declare they have no conflicts of interests.

\section{REFERENCES}

Ahmad, M., \& Sher, H. (2004). Medicinally important wild plants of Chitral, medicinally important wild plants in view of ethnobotanical study of district Chitral PMID. 67, 432-440.

Benevides. P. J. C., Sartorelli, P., Kato, M. J. (1999). Phenylpropanoids and neolignans from Piper regnellii. Phytochem, 52, 339-343. Retrieved from https://doi.org/10.1016/S0031-9422(99)00177-6

CGIAR-CSI (2018). Consortium for spatial information. Retrieved from http://srtm.csi.cgiar.org, (accessed 16 September 2019).

Chen, S. L., Yu, H., Luo, H. M., Wu, Q., Li, C. F., Steinmetz, A. (2013). Conservation and sustainable use of Medicinal plants: problems, progress and prospectus. Chinese Med, 11:37. Retrieved from https://doi.org/10.1186/s 13020-0160108-7.

De-yuan, H. (1997). Paeonia (Paeoniaceae) in Xizang (Tibet). Novon, 156-161. Retrieved from https://doi.org/10.2307/3392188 
Dhyani, S., Maikhuri, R. K., Dhyani, D. (2011). Energy budget of fodder harvesting pattern along the altitudinal gradient in Garhwal Himalaya, India. Biomass bioenergy, 35,1823-1832. Retrieved from https://doi.org/10.1016/j.biombioe.2011.01.022

Gaur, R., D. (1999). Flora of the District Garhwal, North West Himalaya.Transmedia. Retrieved from https://agris.fao.org/agrissearch/search.do?recordID=US201300069963

Hamayun, M. (2004). Studies on ethno botany, conservation and plant diversity of Utror and Gabral valleys, district Swat, Pakistan. Ph. D. thesis submitted to Islamabad, Pakistan:QuaidAzamUniversity, Retrieved from http://eprints.hec.gov.pk/2411/1/2266.

Jain, S. K., \& Rao, R. R. (1977). Handbook of Field and Herbarium Methods. Today and Tomorrow's Printers and Publishers New Delhi, India. Retrieved from https://agris.fao.org/agris-search/search.do?recordID=US201300149187

Joshi, P., Prakash, P., Purohit, V. K., \& Bahuguna, V. (2017). Paeonia emodi: A review of multipurpose wild edible medicinal plant of Western Himalaya. Int. J. Adv. Res, 5, 480-486. Retrieved from https://doi.org/10.21474/IJAR01/5982.

Joshi, P., Prakash, P., Purohit, V. K., \& Joshi, K. (2018). Bioprospecting of Paeonia emodi for livelihood enhancement in Western Himalaya, India. ENVIS Bulletin Him. Ecol, 26, 67-70.

Kala, C. P. (2005). Indigenous uses, population density and conservation of threatened medicinal plants in protected areas of the Indian Himalayas. Conserv. Biol, 19, 368-378. Retrieved from https://doi.org/10.1111/j.15231739.2005.00602.x

Kandari, L. S., Phondani, P. C., Payal, K. C., Rao, K. S., \& Maikhuri, R. K. (2012). Ethnobotanical study towards conservation of Medicinal and Aromatic Plants in upper catchments of Dhauli Ganga in the Central Himalaya. J. Mt. Sci, 9, 286-296. Retrieved from https://doi.org/ 10.1007/s11629-0122049-7.

Khan, T., Ahmad, M., Nisar, M., Ahmad, M., Lodhi, M. A., \& Choudhary, M. I. (2005). Enzyme inhibition and radical scavenging activities of aerial parts of Paeonia emodi Wall. (Paeoniaceae). J. Enzyme Inhib. Med. Chem, 20(3), 245-249. Retrieved from https://doi.org/10.1080/14756360400026220

Maikhuri, R. K., Nautiyal, S., Rao, K. S., \& Saxena, K. G. (1998). Medicinal plants cultivation and Biosphere Reserve management: a case study from Nanda Devi Biosphere Reserve, Himalaya. Curr. Sci, 74: 157-163. Retrieved from https://www.jstor.org/stable/24100465

Malik, Z. A., Bhat, J. A., Ballabha, R., Bussmann, R. W., \& Bhatt, A. B. (2015). Ethno medicinal Plants Traditionally Used in Health Care Practices by Inhabitants of Western Himalaya. J. Ethnopharmacol, 172(22), 133-144. Retrieved from https://doi.org/10.1016/j.jep.2015.06.002

Misra, R. (1968). Ecology Work Book. Oxford and IBM publishing Company Calcutta, 244.

Munir, O., \& Rehman, K. (2018). Plant and Human Health Volume 1: Ethnobotany and Physiology. Springer.

Naithani B D (1984). Flora of Chamoli district.Vol.I \& II. Botanical Survey of India, Howrah. Retrieved from https://agris.fao.org/agrissearch/search.do?recordID=US201300396688

Nautiyal, S., Maikhuri, R. K., Rao, K. S., \& Saxena, K. G. (2001). Medicinal Plant Resources in Nanda Devi Biosphere Reserve in the Central Himalaya. J. 
Herbs Spices Med. Plants, 8, 47-64. Retrieved from https://doi.org/10.1300/J044v08n04_06

Negi, V. S., Maikhuri, R. K., Maletha, A., \& Phondani, P. C. (2018). Ethnobotanical Knowledge and Population Density of Threatened Medicinal Plants of Nanda Devi Biosphere Reserve, Western Himalaya, India. Iran. J. Sci. Technol. Trans. A: Sci, 43, 63-73. Retrieved from https://doi.org/10.1007/s40995-0180545-5

Pavela, R. (2004). Insecticidal activity of certain medicinal plants. Fitoterapia, 75, 745-749. Retrieved from https://doi.org/10.1016/j.fitote.2004.08.005

Phondani, P. C., Maikhuri, R. K., \& Bisht, N. S. (2009). Medicinal plants used in the health care system practiced by traditional Vaidyas in Alaknanda catchment of Uttarakhand, India. Ethnobot. Leafl, 4. Retrieved from https://opensiuc.lib.siu.edu/cgi/viewcontent.cgi?referer=https://scholar.g oogle.com/\&httpsredir $=1$ \&article=1655\&context $=$ ebl

Prakash, P., Joshi, P., \& Purohit, V. K. (2020). Impact on Density of Paeonia emodi alongAltitudinal Gradient in Garhwal Himalaya, India. Appl. Eco. Environ. Sci, 8(5), 319-323.

Rawat, B., Gairola, S., \& Bhatt, A. (2010). Habitat characteristics and ecological status of Paeonia emodi Wall. ex Royle: A high value medicinal plant of West Himalaya. Int. J. Phytomed. Rel. Indus, 2, 139-143. Retrieved from https://doi.org/10.5958/j.0975-4261.2.2.021

Riaz, M., Zia-Ul-Haq, M., \& Jaafar, H. Z. E. (2013). Common mullein, pharmacological and chemical aspects. Braz. J. Pharmacogn, 23, 948-959. Retrieved from https://doi.org/10.1590/S0102-695X2013000600012

Semwal, D. P., Saradhi, P. P., Nautiyal, B. P., \& Bhatt, A. B. (2007). Current status, distribution and conservation of rare and endangered medicinal plants of Kedarnath Wildlife Sanctuary, Central Himalaya, India. Curr. Sci, 92(12), 1733-1738. Retrieved from https://www.jstor.org/stable/24107624

Shinwari, Z., Khan, A., \& Nakaike T (2003). Medicinal and other useful plants of district Swat, Pakistan. Aziz Communic. Peshawar, Pakistan, pp139-145.

Vashistha, R., Nautiyal, B. P. \& Nautiyal, M. C. (2006). Conservation status and morphological variations between populations of Angelica glauca Edgew. and Angelica archangelica Linn. in Garhwal Himalaya. Curr. Sci, 91(11), 1537-1542. Retrieved from https://www.researchgate.net/profile/McNautiyal/publication/237597009_Conservation_status_and_morphological _variations_between_populations_of_Angelica_glauca_Edgew_and_Angelica _archangelica_Linn_in_Garhwal_Himalaya/links/0deec52981ee750213000 000/Conservation-status-and-morphological-variations-betweenpopulations-of-Angelica-glauca-Edgew-and-Angelica-archangelica-Linn-inGarhwal-Himalaya.pdf

Watt, G. (1982). Dictionary of economic products of India, Cosmo publication Delhi, India, 6, 3. 